\title{
Matlab application on ecotechnic analysis of Vietnam wind power project
}

\author{
Úng dụng Matlab trong phân tích kinh tế kỹ thuật các dụ án điện gió của Việt \\ Nam \\ Research article
}

Thanh, Le Xuan*

Hanoi University of Mining and Geology, Vietnam

\begin{abstract}
Vietnam has fundamental advantages to implement the wind power project. Because of being surrounded by sea areas, wind power projects in Vietnam have a promise future. However, implementing an ecotechnic analysis of a wind power project has a fairly challenge because of seasonal change as well as input data's fluctuation. The paper presented a method based on Matlab programming utilized for ecotechnic analysis the wind power projects. The math diagram built with the consideration of all input data's changing will be shown to make the ecotechnic analysis easier and faster. The results deducted from Matlab programming will be compared with ones made by expertise method. The conclusion about advantages of method is pointed out to help project managers have another choice in making ecotechnic analysis of wind power project.
\end{abstract}

Việt Nam có nhũ̃ng thuận lợi co bản để thực thu các dư án điện gió. Do đặc điểm địa lý, bao quanh bởi khá nhiều các vùng biển, các dụ án điện gió của Việt Nam có tính khả thi và một tương lai đầy hứa hẹn. Tuy vậy, thực thi các phân tích kinh tế kỹ thuật của một dụ án điện gió có thách thức không nhỏ bởi những thay đổi của yếu tố mùa cũng nhu nhũng thay đổi của các yếu tố đầu vào. Bài báo giới thiệu một phương pháp dụa vào quá trình lập trình trên Matlab, ưng dụng để phân tích kinh tế kỹ thuật các dụ án điện gió. Luu đồ thuật toán được xây dụng có xem xét đến sư thay đổi của các yếu tố đầu vào sẽ giúp quá trình phân tích nhanh hơn và dễ dàng hơn. Các kết quả thu đuợc sẽ được so sánh với các kết quả được tiến hành theo phương pháp chuyên gia. Kết luận về nhüng uu điểm của phuoong pháp cũng được đưa ra để giúp các nhà quản lý các dụ án điện gió có đuoợc lưa chọn nữa trong tiến hành phân tích kinh tế kỹy thuật các dụ án điện gió.

Keywords: wind power project, ecotechnic analysis, Matlab programming, mathdiagram

\section{Wind power projects in Vietnam: general introduction, opportunities and challenges}

In world wide, wind power reach very amazing capacity by the end of 2015. The worldwide wind capacity reached $392^{\prime} 927$ MW by the end of June 2015, out of which 21'678 MW were added in the first six months of 2015 [2]. The total capacity of wind power in the world is shown in figure 1 .
In Vietnam, however, wind power and wind power projects still get great challenges in comparing with fossil energy because of high investment. Going in parallel with the new achievements of modern technology, the price of one $\mathrm{kWh}$ wind energy is dramatically decreased. The detail shown in figure 2 brings a bright future for wind power project in Vietnam. 


\section{Total Installed Capacity 2011-2015 [MW]}

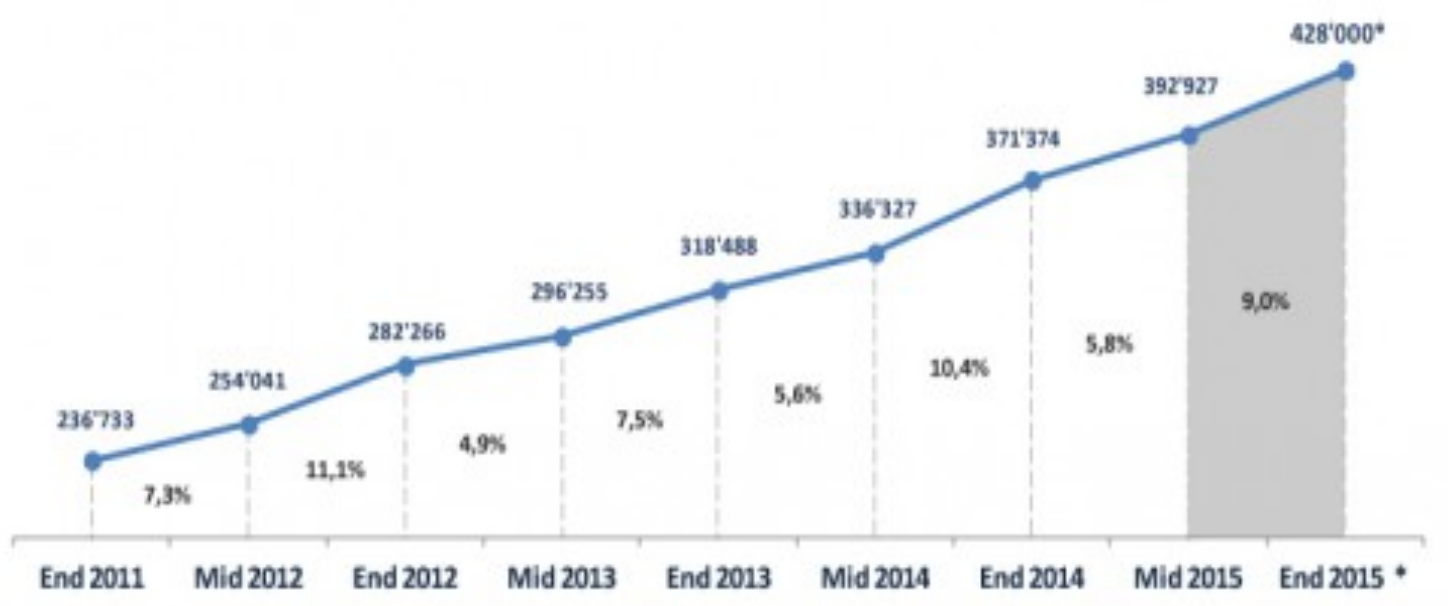

- Estimated

Total installed capacity: Includes all installed wind capacity, connected and not-connected to the grid.

O WWEA - 2015

Figure 1: Total capacity of wind power from 2011 to 2015

\section{COST OF WIND ENERGY}

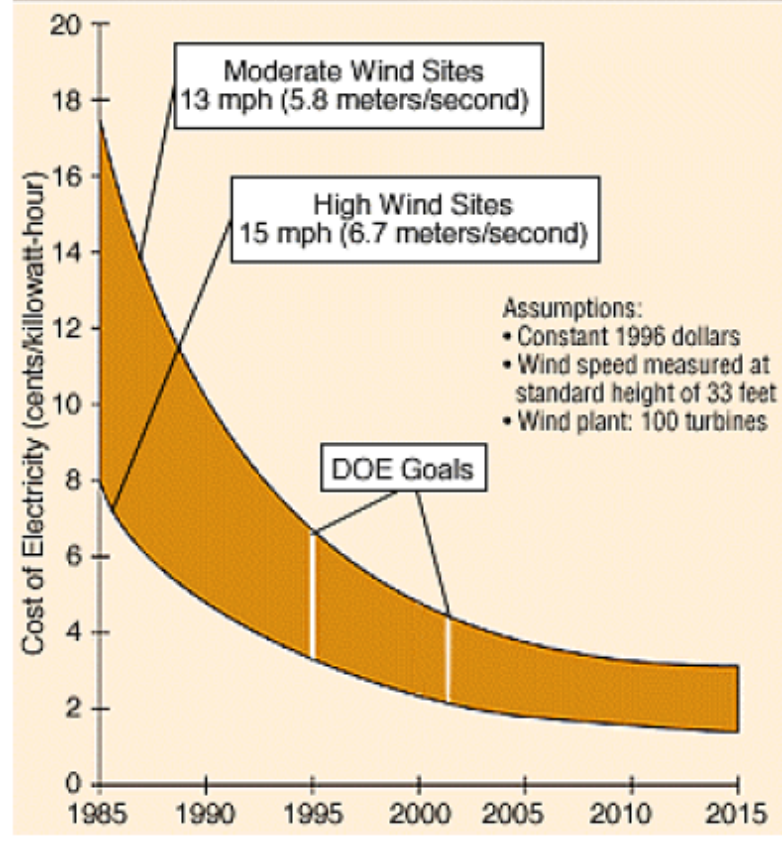

Figure 2: Trend of wind energy's cost [1]

Many provinces in Vietnam have rich wind power resources. Because of their advanced geological characters the potential of wind energy in Vietnam was estimated about 513,360 MW, equivalent to approximately six times higher than the predicted capacity of the electricity sector by 2020 . The most promising areas for wind energy development are located in coastal and highland areas in the south-centre and southern parts of Vietnam. The World Bank's study also estimated of about $8.6 \%$ of the total land area of Vietnam to have the wind resources from "high" to "very high" potential for the development of large wind energy turbine (wind speed $>7 \mathrm{~m} / \mathrm{s}$ ) [7].
For instance, in QuangBinh province, the measurements of wind velocity and wind distribution at the height of $80 \mathrm{~m}$ show that it is definitely able to build an area of wind generators. However, making an investment in wind power project needs a careful analysis both in technical matter and in economic considerations.

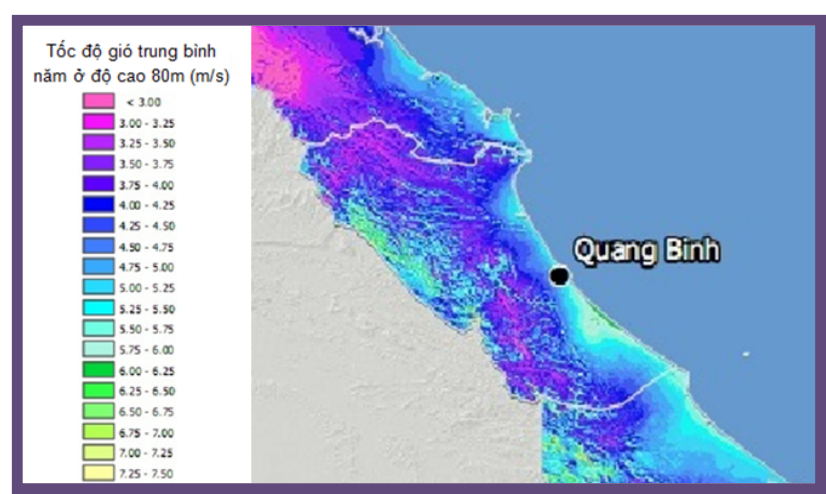

Figure 3: The measurements of wind velocity at $80 \mathrm{~m}$ [5]

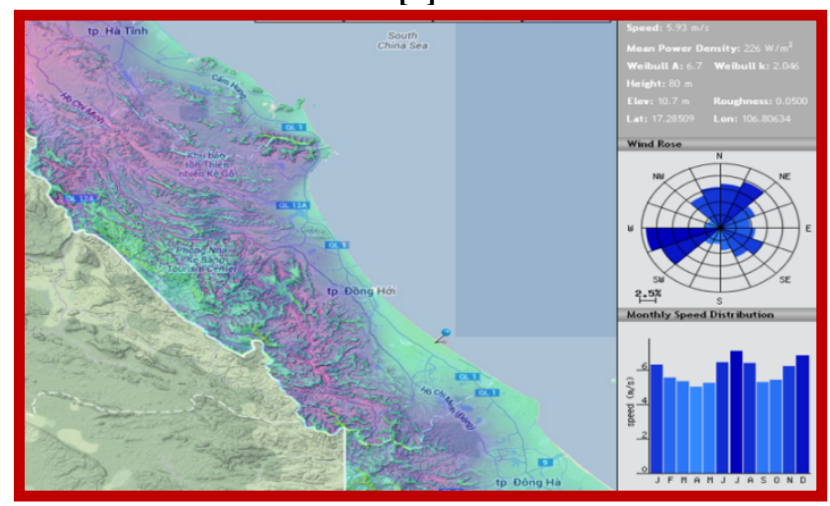

Figure 4: The distribution and direction of wind at $80 \mathrm{~m}[5]$.

Investment in wind energy is found in both off-grid and ongrid projects throughout Vietnam. Off-grid wind power projects have been implemented recently in some provinces. These projects are scattered and are on a scale of 20 
$\mathrm{kW}$ or smaller. Wind projects that were implemented previously are no longer in operation due to equipment longevity or lack of maintenance [7].

On-grid wind power projects are new in Vietnam. Gridconnected projects are concentrated in southern coastal areas especially Binh Thuan and Ninh Thuan provinces. By 2010 there were 37 wind field projects in this area. They belong to 31 investors and are at different investment stages of development with a total registered capacity of $3,837 \mathrm{MW}$. There is one project in first phase operation (7.5 MW), 2 projects at the technical design stage, and 12 projects that are completing feasibility study reports [7].

The main obstacle for investment in wind power is the electricity purchasing price. Beside this issue, another matter is the right calculation of investment for long energy transmission from wind station. The introduction of Matlab application on analysis the investment is shown below.

\section{Matlab application on ecotechnic analysis the wind power project}

\subsection{Basic concepts and math diagrams}

\subsubsection{Mathematic basic utilized in forming the cost} function

An energy project needs to determine the recovering time. As usual, an assumption of cost function is presented by equation (1) [1].

$$
Z=\left(a_{v h}+a_{t c}\right) K+Y_{\Delta A}
$$

Whereas: $\quad \mathrm{a}_{\mathrm{vh}}$-the operation factor; $\mathrm{a}_{\mathrm{tc}}$-standard recovery factor.

K-Annual cost
$\Delta \mathrm{A}$-Power losses when wind power is transmitted for long distance.

More detail, $\mathrm{Z}$ can be also expressed by equation (2):

$Z=\left(a_{v h}+a_{t c}\right) C_{d d} m_{0} \ell+C \frac{\left(P^{2}+Q^{2}\right)}{U^{2}} \tau \frac{\delta}{S} \ell$

The equation above show the relation of $Z=f(U, S$. ) Similarly, a cost function of Investment and its impact factors could be built to make an ecotechnic analysis of a wind project. The detail will be shown in 2.2.2.

\subsubsection{Block diagram}

To solve the cost function $\mathrm{Z}$ for finding the optimal value, many solutions can be applied. One of this is a method utilizing Matlab programming with maths diagram shown in figure 5 .

\subsection{The results}

\subsubsection{Results from calculating the cost function}

Utilizing the above maths diagram, programming in Matlab, curves shown in figure 6 and 7 are formed to help the finding of $Z$ function's optimal value. The detail of calculation corresponding to some type of conductors is presented in table 1 .

Table 1: Some results of $\mathrm{Z}$ calculation

\begin{tabular}{|c|c|c|c|c|}
\hline \multirow[t]{2}{*}{ Type } & \multicolumn{4}{|c|}{ Annual cost function $Z=f\left(U^{2}\right),\left(10^{6} V N D\right)$} \\
\hline & $6 \mathbf{k V}$ & $10 \mathrm{kV}$ & $22 \mathrm{kV}$ & $35 \mathrm{kV}$ \\
\hline AC70 & $47.446,83$ & $20.912,15$ & $9.070,23$ & $7.204,83$ \\
\hline AC95 & $39.741,99$ & $20.190,12$ & $11.464,50$ & $10.089,99$ \\
\hline AC24 & $39.960,928$ & $32.221,64$ & $28.767,75$ & 28.223,67 \\
\hline $\mathbf{0}$ & & 8 & 4 & 8 \\
\hline
\end{tabular}




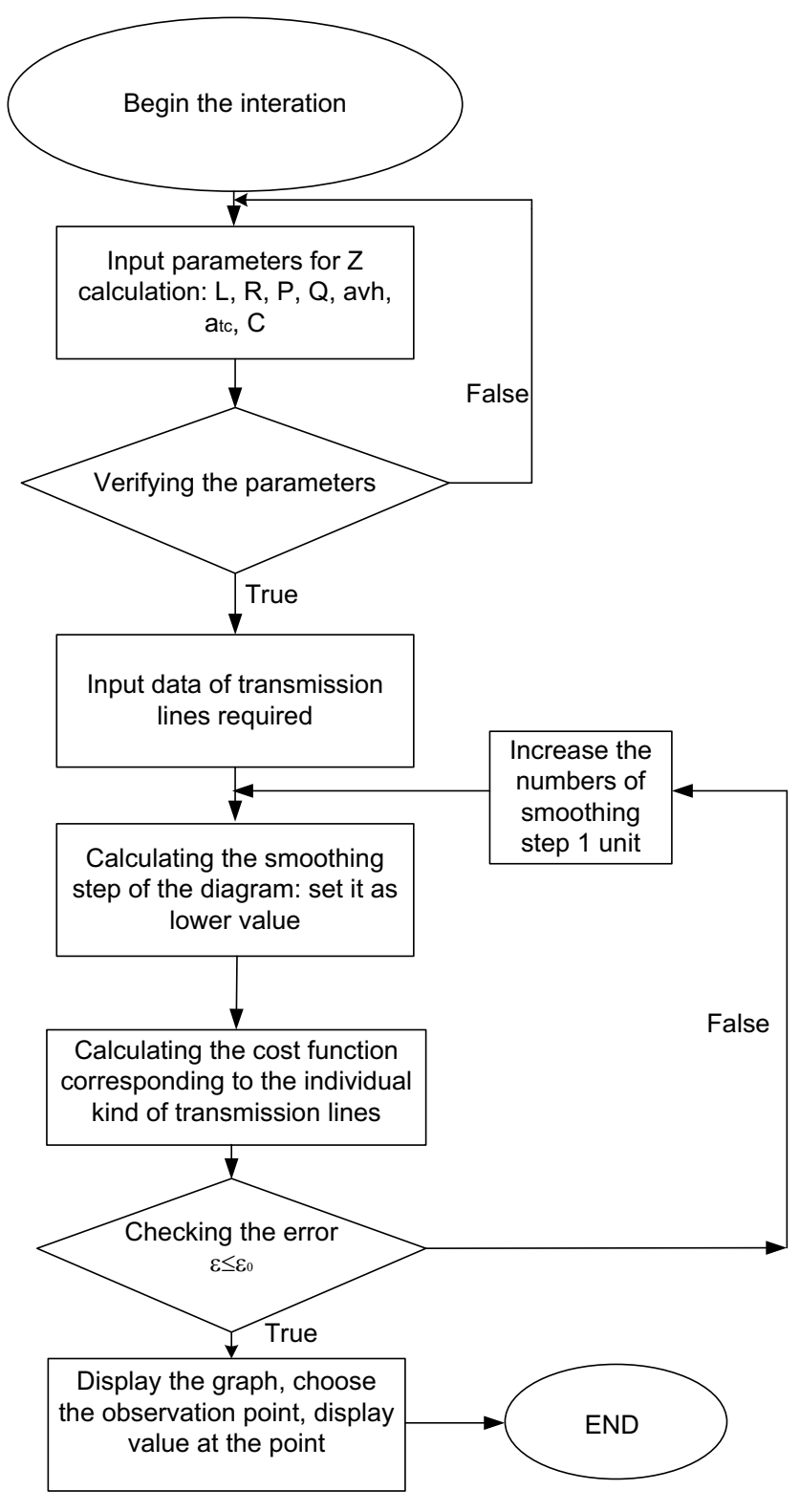

Figure 5. Maths diagram presented the calculation for optimal value of Cost function $Z$

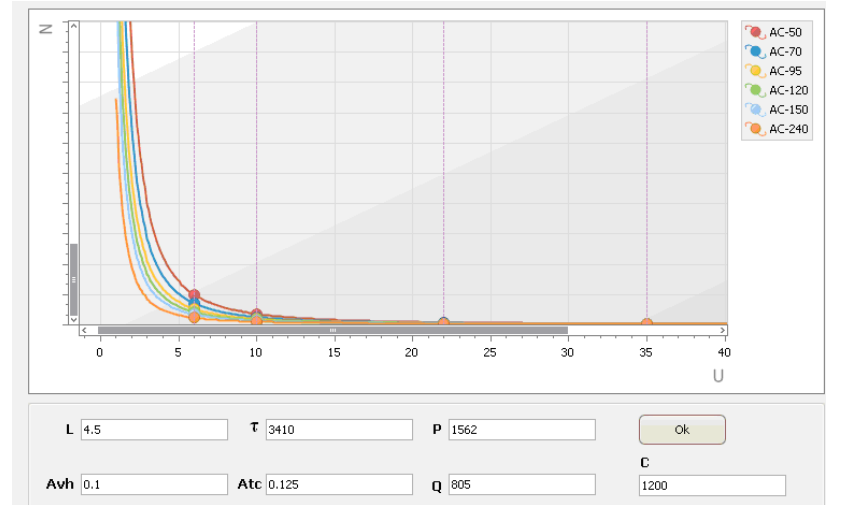

Figure 6: Results corresponding to different type of conductor

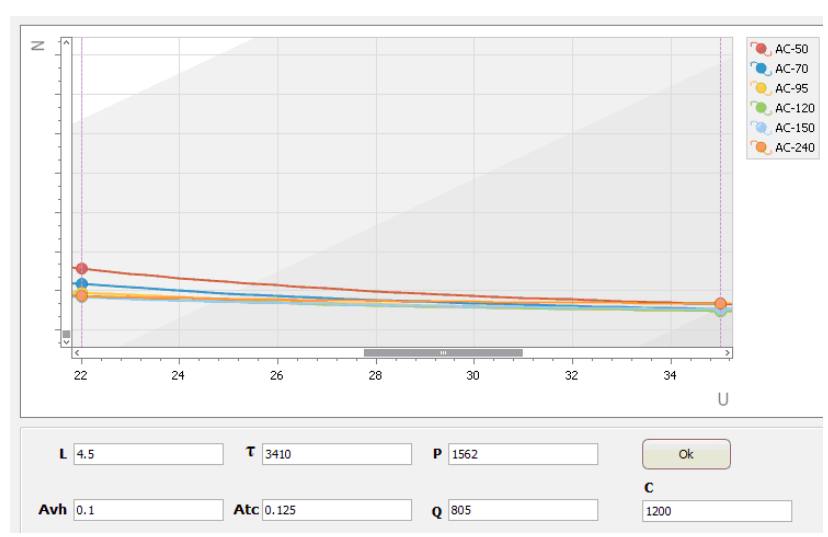

Figure 7: Results corresponding to different type of conductor and different input parameters.

2.2.2 Comparison of results calculated from soft ware and from expertise method 
Utilizing the maths diagram in figure 5 and the same input parameters of expertise method, the detail calculation of two methods is shown in table 3 (Quang Ninh) and in table 4 (Le Thuy).
There is a slight difference between two methods $(10,48$ $10,58)$ and $(11,18-11,09)$. The difference is under $1 \%$ and can be accepted some cases.

Table 2. Ecotechnic analysis the wind project in Quang Ninh

\begin{tabular}{|c|c|c|c|c|}
\hline \multirow{2}{*}{$\mathbf{T T}$} & \multirow{2}{*}{ Parameter } & \multirow{2}{*}{ Unit } & \multicolumn{2}{|c|}{ Quang Ninh } \\
\hline & & & Expertise & Matlab utilized \\
\hline 1 & Type of wind Generator & MW & 2 & 2 \\
\hline 2 & Total capacity & MW & 30 & 30 \\
\hline 3 & Rated investment & USD/kW & 2.150 & 2.150 \\
\hline & - Equipment & $\mathrm{USD} / \mathrm{kW}$ & 1.450 & 1.450 \\
\hline & - Installation cost & $\mathrm{USD} / \mathrm{kW}$ & 800 & 800 \\
\hline 4 & Maintenance & (USD/MWh) & 30 & 30 \\
\hline 5 & Annual generating Capacity & (MWh/year) & 73.649 & 73.580 \\
\hline 6 & Age & years & 20 & 20 \\
\hline 7 & Price & centUS\$/kWh & 10,58 & 10,48 \\
\hline
\end{tabular}

Table 3: Ecotechnic analysis the wind project in Le Thuy

\begin{tabular}{clccc}
\multirow{2}{*}{ TT } & \multicolumn{1}{c}{ Parameter } & Unit & \multicolumn{2}{c}{ Le Thuy } \\
\cline { 4 - 5 } & & $\mathrm{MW}$ & 2 & Mxpertise \\
2 & Type of wind Generator & $\mathrm{MW}$ & 30 & 30 \\
2 & Total capacity & $\mathrm{USD} / \mathrm{kW}$ & 2.150 & 2.150 \\
3 & Rated investment & $\mathrm{USD} / \mathrm{kW}$ & 1.450 & 1.450 \\
& $-\quad$ Equipment & $\mathrm{USD} / \mathrm{kW}$ & 800 & 800 \\
& $-\quad$ Installation cost & (USD/MWh) & 30 & 30 \\
4 & Maintenance & (MWh/year) & 72.270 & 72.330 \\
5 & Annual generating Capacity & years & 20 & 20 \\
6 & Age & centUS\$/kWh & $\mathbf{1 1 , 1 8}$ & $\mathbf{1 1 , 0 9}$
\end{tabular}

\section{Conclusion}

Base on the above calculations, Matlab utilizing method in making ecotechnic analysis proved its self effectiveness. In some cases, that cannot determine or implement expertise method, using Matlab is a smart alternative.

Even a slight error can be get, but Matlab utilizing method has a great advantage of fast computing, reliable result. It also has a flexible calculation, any when an input parameter is changed, the calculation procedure could be done without any requirements;

In the beginning stage of ecotechnic analysis of a wind project, using the method is a good recommendation that give project manager have a general review about the economical effectiveness of the project.

\section{References}

[1] Trends in wind energy costs, US. DOE; http://www.eren.doe.gov/wind/wttr.html
[2] WWEA, Wind power Total install capacity to the year 2015. http://www.wwindea.org/hyr2015/

[3] http://www.wwindea.org/small-wind-world-marketback-on-track-again/

[4] Vietnam national Institue of Energy, , "Renewable energy analysis of QuangBinh province" Technical Report, 2014.

[5] Map of Vietnam wind power resources, AWS truepower, 2010

[6] https://energypedia.info/wiki/Wind_Energy_Country_Analysis_Vietnam

[7] http://www.renewableenergy.org.vn/index.php?page $=$ overview

[8] Dang Quang Khoa, "Research to plan the MV grid of QuangNinh Province suited to the development of economic and social characteristics to the year 2020", Doctor dissertation, 2010, University of Mining and Geology. 